\title{
Fifty years of rodent eradications in New Zealand: another decade of advances
}

\author{
James C Russel1 ${ }^{1,2, *}$ and Keith G Broome ${ }^{3}$
}

${ }^{1}$ School of Biological Sciences, University of Auckland, Private Bag 92019, Auckland, New Zealand

${ }^{2}$ Department of Statistics, University of Auckland, Private Bag 92019, Auckland, New Zealand

${ }^{3}$ Science and Policy Group, Department of Conservation, Hamilton 3240, New Zealand

* Author for correspondence (Email: j.russell@auckland.ac.nz)

Published online: 12 January 2016

\begin{abstract}
New Zealand has just passed half a century of rodent eradications on islands. Confirmation of the first rat eradication in New Zealand on Maria Island/Ruapuke coincided with the devastating rat invasion on Big South Cape Island/Taukihepa. We review the early history of rodent management in New Zealand leading up to and including the Big South Cape Island/Taukihepa ship rat invasion, and document the development and implementation of rodent eradication technologies on New Zealand islands up to the present day. In the last decade major advances have been made in multi-species eradications including rodents, community engagement, mouse eradication, transferring techniques to mainland eco-sanctuaries, and developing new tools for rodent management. The challenge of rodent biosecurity to prevent reinvasion which loomed large only a decade ago, is now being addressed through a combination of research and robust management procedures. Increased emphasis is now being placed on documenting species and ecosystem recoveries following rodent eradication. We identify the major challenges to further expansion of rodent eradication throughout New Zealand as working with multiple stakeholders on inhabited islands, efficiencies of scale on very large islands, and the implementation of cost-effective barrier technologies on the New Zealand 'mainland'.
\end{abstract}

Keywords: biosecurity, conservation, islands, mice, Mus, rats, Rattus

\section{Introduction}

New Zealand is generally considered the world leader in rodent eradications on islands (Rauzon 2007; Keitt et al. 2011), and with good reason. Over the past 50 years introduced mammals have been cleared from 117 islands (Towns et al. 2013). In September 2014 these successes were celebrated with a full day symposium held at the University of Auckland where 15 speakers presented an overview of major contributions to rodent eradications in New Zealand. This special issue presents papers from the symposium and additional work in the theme of rodent eradication on islands. It is fitting that the special issue appears in the New Zealand Journal of Ecology which has over those same 50 years published many of the landmark papers in introduced mammal management in New Zealand(e.g. Taylor 1968; Atkinson 1973; Moors 1985; Taylor \& Thomas 1989; Innes \& Barker 1999; Hoare \& Hare 2006; Bellingham et al. 2010; Parkes \& Nugent 2011; Towns et al. 2012). Here, we summarise some of the less well documented early history of rodent management in New Zealand and update previous reviews (Thomas \& Taylor 2002; Towns \& Broome 2003; Clout \& Russell 2006; Howald et al. 2007; Broome 2009; Towns 2011; Towns et al. 2013) with a focus on the past decade of invasive rodent management on New Zealand islands.

\section{History}

The impacts of invasive rodents (Rattus ratttus, $R$. norvegicus, $R$. exulans and Mus musculus) in New Zealand have been well documented since the start of the $20^{\text {th }}$ century (Thomson 1922; Wodzicki 1950), and in this issue Rowley Taylor (2016) presents a personal recollection of the earlier work he was involved in from the just after World War II through to the landmark 1976 national symposium by the Department of Lands and Survey (Dingwall et al. 1978). This early work was important, already foreshadowing many issues in introduced mammal eradication such as indirect effects of multi-species interactions (Taylor 1968, 1979a, b) that would not be properly picked up again until the early $21^{\text {st }}$ century (Courchamp et al. 2003). The 1976 symposium brought together many of the country's leading experts, both managers and scientists, and the original list of participants contains people still active 40 years later. Since that symposium, New Zealanders have got on with eradicating rodents from islands (Veitch et al. 1992; Clout \& Russell 2006), hosting important meetings about every decade; one national symposium in 1990 (Towns et al. 1990 ) on island restoration and two international conferences in 2001 (Veitch \& Clout 2002) and 2010 (Veitch et al. 2011) on invasive species eradications on islands. Importantly, this concerted conservation work has been led by wildlife managers getting on with the task using the best available scientific evidence (Towns et al. 2013), but also not being delayed by calls for further research before taking action (Grantham et al. 2009). Rodent eradications do not always have to happen immediately, but there remains an urgency with which rodents must be eradicated from islands anywhere in the world (Russell \& Holmes 2015) and this sense of urgency underlies thinking about threatened species management in New Zealand (Department of Conservation 2014) .

\section{Big South Cape Island/Taukihepa}

The eradication of Norway rats from Maria Island/Ruapuke in 1959 (confirmed in 1964) by Don Merton from the NZ Wildlife Service, with the support of Forest and Bird, was the 
first rodent eradication in New Zealand. However the invasion of Big South Cape Island by ship rats in 1963 was the event that was truly instrumental in redefining the tone of introduced rodent management in New Zealand. Along with the raising of Lake Manapouri (Mark et al. 2001), and the proposed mining of Coppermine Island (Newhook 1969), the invasion of Big South Cape Island was one of the landmark events of the 1960s which went on to define the emerging modern environmental movement in New Zealand (Young 2004). However, the events on Big South Cape Island were only ever recorded briefly in the proceedings of the 1976 symposium (Bell 1978), and did not receive as much media coverage as the other issues. In this special issue, three papers finally address this lack of literature on the rat invasion of Big South Cape Island. Biz and Brian Bell, supported by the work of the late Don Merton, describe in detail the initial rat invasion and aftermath on Big South Cape Island (Bell et al. 2016). Grant Harper and Malcolm Rutherford (2016) then detail the population demography of the unique Big South Cape Island rat population just prior to its eradication. Finally Judith Robins and colleagues (Robins et al. 2016) use modern molecular tools to show clearly that the rat invasion of Big South Cape Island was indeed most likely from a vessel having travelled from the South Island, as was originally hypothesised but never able to be confirmed (Bell 1978). With the eradication of rats from Big South Cape and neighbouring islands in 2006, using funds from the Command oil spill (McClelland et al. 2011), these three papers help draw to a close this chapter of New Zealand rodent ecology history which saw numerous species extinctions and local extirpations (Towns \& Broome 2003).

\section{Development}

The huge successes of rodent eradications in New Zealand have been driven by incremental work over many decades, starting with small islands (Taylor \& Thomas 1989, 1993; McFadden \& Towns 1991; McFadden \& Greene 1994) and gradually increasing scale (Thomas \& Taylor 2002), all the while developing and building capacity (Cromarty et al. 2002; Broome et al. 2011) to tackle larger, more complex islands (Towns \& Stephens 1997; Broome 2009; McClelland 2011; Springer 2016). The breakthrough which allowed these advances was the development of slow acting second generation anticoagulants in the late 1970s. For the first time rodents could eat a lethal dose in a single or many small meals yet not feel the effects for several days (Hadler \& Buckle 1992). Poison shyness, which hampered earlier eradication attempts with toxicants, was eliminated. The first successes from deliberate attempts in the 1980s opened the minds of many to the conservation possibilities. The old adage 'success breeds success' held true for rodent eradications with a surge of projects in New Zealand in the 1990s (Figure 1).

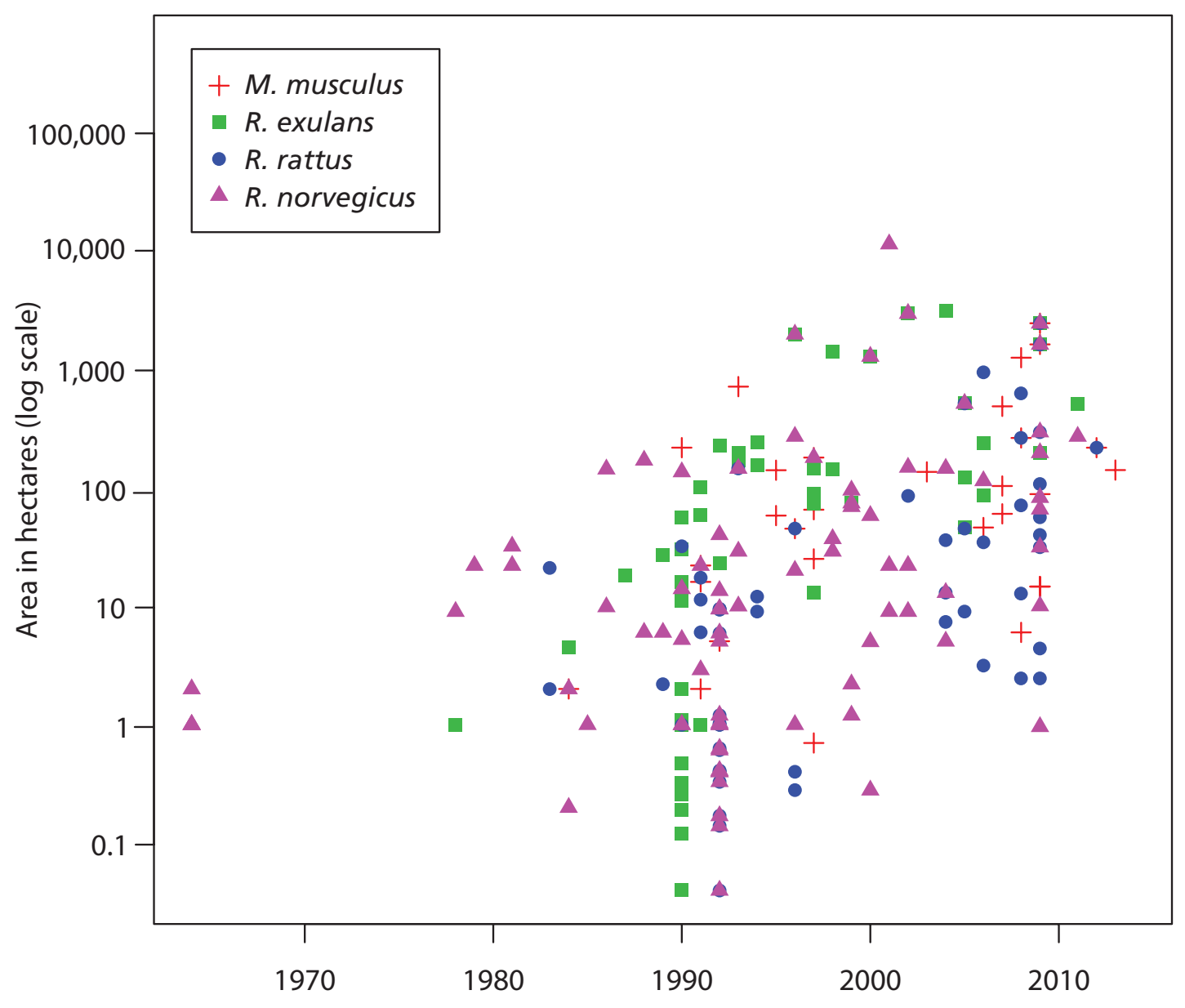

Date Confirmed

Figure 1. Fifty years of rodent eradications in New Zealand 1964-2014 (updated from Clout \& Russell 2006). 
Aerial baiting had been used to control possums on the mainland of New Zealand since the 1950s, firstly using fixed wing aircraft and increasingly using helicopters with underslung bucket spreaders (Montague 2000). The first attempt to use this technology in an eradication targeting rodents was in 1986 on Whale Island/Moutohora (Jansen 1993) but larger, more complex islands did not become feasible until Global Positioning System (GPS) based navigational guidance became available in the mid-1990s. This technology allowed thorough coverage of larger islands by guiding the aircraft along predetermined flight lines, whilst recording where the aircraft actually flew to allow mapping and re-sowing of any suspected gaps in coverage. This development was a turning point for larger eradication projects, beginning with Kapiti Island in 1996 (Empson \& Miskelly 1999; Howald et al. 2007; Broome 2009). Underlying the technology developments for aerial baiting was a corresponding development of pilot skill in using the equipment with the degree of proficiency required to achieve eradication. The large agricultural aviation industry in New Zealand was an important factor in this by allowing pilots to acquire a high level of skill on other similar work such as possum baiting, fertiliser spreading and crop spraying using navigational guidance.

\section{Advances}

Since the eradication of Norway rats from 11,300 hectare Campbell Island in 2001 (McClelland 2011), coinciding with the review of rodent eradications in New Zealand at the fortieth anniversary (Towns \& Broome 2003), we have not in fact increased further in scale (Figure 1). Instead, the focus of island eradication has changed to other challenges beyond scale (Holmes et al.2015), particularly a focus on multi-species eradications. All three invasive rat species were simultaneously targeted on Pearl Island, which was operationally successful but the restoration ultimately failed due to unanticipated high levels of swimming reinvasion (Russell et al. 2010b). By far the greatest achievement to date has been the eradication of eleven introduced mammal species from combined RangitotoMotutapu Islands in two campaigns fifteen years apart, eight of these being in the final campaign (Griffiths et al. 2015). This multi-species approach over-rides many of the concerns of indirect effects of single invasive species removal which arose over the same period (Courchamp et al. 2003; Dowding et al. 2009).

At the same time, the role of stakeholder and landowner engagement became more prominent over the past decade. Eradication of Pacific rats (kiore) from Little Barrier Island/ Hauturu-O-Toi in 2004 required extensive negotiations between the Department of Conservation and historic customary land-owners Ngatiwai (Kapa 2003). The Department of Conservation has now removed rodents and other introduced mammals from most islands under its jurisdiction, typically small and uninhabited islands. This now means the role of social engagement to progress rodent eradications on other islands, particularly inhabited islands, has grown to prominence, both in New Zealand and internationally (Oppel et al. 2011; Glen et al. 2013).

Attention over the past decade has also turned to mice, recognising that they are not just small rats when it comes to eradication (Clapperton 2006; Angel et al. 2009). Mouse eradications have historically had a much lower success rate than rat eradications (MacKay et al. 2007) but subsequent investment in research has answered many of the unknowns
(MacKay et al. 2011,2013). However, at the same time mouse invasion and reinvasion of islands, particularly in the upper South Island, poses ongoing challenges. Nonetheless, today eradication of mice from large islands such as 2,012 hectare Antipodes Island is planned (Elliott etal.2015). This eradication should pave the way for even larger mouse eradications such as on Gough and Marion Islands which are desperately required for seabird conservation (Davies et al. 2015).

Islands have acted as arks for New Zealand conservation precisely because of their isolation and the barriers to reinvasion. However, not all threatened species are suitable for island translocation and large tracts of indigenous land cover on the 'mainland' North and South Islands also warrant conservation protection. Fences have long been used in New Zealand as a barrier to pest movement (Aviss \& Roberts 1994), but in the 1990s the level of sophistication in fence design allowed them to be used for the first time to exclude rodents, although mouse eradication and reinvasion prevention pose ongoing challenges (Burns et al. 2012). Predator-proof fenced reserves provide an island analogue on the mainland, where rodents can be eradicated, and reinvasion managed to reasonable levels, using the same techniques as on islands. However, the cost of erecting and maintaining predator-proof fences is substantial, and debate exists on the value-for-money that fenced reserves return (Scofield et al. 2011; Innes et al. 2012), compared to unfenced 'mainland islands' (Saunders \& Norton 2001).

Novel tools and technologies are also being brought to bear on the challenge of rodent eradications from islands. Rodent eradication is still dominated by a single method: ground or aerial distribution of the second generation anti-coagulant toxin brodifacoum (Holmes et al. 2015). This method has worked in New Zealand, but not necessarily elsewhere, such as in the tropics (Russell \& Holmes 2015), or where public acceptability is lacking (Ogden et al. 2009), or non-target risk is too high (Pitt et al. 2015). Therefore, over the past decade much work has gone into developing new technologies which might have application to rodent eradication and biosecurity (Blackie et al. 2014) and scanning for future technologies which might one day have an important role (Campbell et al. 2015). Recent work on 64 hectare Native Island suggests a self-resetting trap network may allow eradication without toxin to scale up without the commensurate increase in labour (Peters 2015). Statistical tools are also now available to allow eradication managers to confirm eradication success much faster than the traditional 'wait-and-see' approach after two years (Samaniego-Herrera et al. 2013).

\section{Biosecurity}

By far the greatest advance over the past decade of rodent eradications in New Zealand has not been in removing rodents, but in keeping them off islands from which they are not present. At the start of the $21^{\text {st }}$ century the risk of rodents reinvading islands was considered high and our ability to prevent reinvasions low (Dilks \& Towns 2002; Towns \& Broome 2003). Rodent incursions on New Zealand islands have been recorded at an increasing rate (Russell \& Clout 2005), which is unsurprising since there has also been an increasing number of islands cleared of invasive rodents. The average time to reinvasion was estimated at around only ten years (Clout \& Russell 2008). This risk and lack of knowledge spurred a large body of research in the field of rodent biosecurity both in New Zealand (Russell et al. 2007, 2008b) and Australia (Greenslade et al. 2013). 
Initial work focused on the behavioural ecology of invading rats and mice (Russell et al. 2010a; MacKay 2011) and their detection in surveillance grids (Russell et al. 2008a; Innes et al. 2011; Nathan et al. 2013), utilising the novel experimental approach of intentional introductions. The first introduction was a very elusive and hard to detect Norway rat named Razza (Russell et al. 2005; Ihimaera 2006), but the approach finally culminated in the intentional invasion of an entire (small) island by mice (Nathan et al. 2015). Additional work focused on novel tools in rodent biosecurity such as the use of trained conservation dogs (Gsell et al. 2010) and laboratory rats as social attractants (Shapira et al. 2013).

The landmark eradication of introduced mammals from Rangitoto-Motutapu Islands also raised the issue of high human-mediated reinvasion risk for a group of islands near the largest city in New Zealand, and prompted the creation of the joint agency Treasure Islands programme in the Hauraki Gulf which Imogen Bassett and colleagues detail in this issue (Bassett et al. 2016). Rodent incursions are now intercepted with such reliability that very few lead to full island reinvasions (Masuda \& Jamieson 2013). These advances in biosecurity have been supported by technical developments such as molecular tools to allow eradication managers to discriminate eradication failure from reinvasion (Russell et al. 2010b) and biomarker tools to allow eradication managers to identify reinvasion source sites (Bagasra et al. 2016).

\section{Restoration}

The past decade has also seen a growing published knowledge base of species and ecosystem recoveries following rodent eradications, particularly for some of the earliest eradications. Most examples of recoveries had previously been anecdotal or limited to single species following eradication (e.g. Newman 1994; Miskelly \& Fraser 2006; Towns et al. 2007), but there has been a growing demand for scientific evidence of recoveries to justify further investment in new eradications both locally and internationally, and ongoing investment in rodent biosecurity (Jones 2010). Throughout the early $21^{\text {st }}$ century the Rats And Seabird Project (RASP) used rat invasions of islands in the Hauraki Gulf as a large-scale natural experiment to investigate the impacts of rat invasion, particularly seabird extirpation, on ecosystem processes (Fukami et al. 2006; Mulder et al. 2009; Towns et al. 2009; Wardle et al. 2009; Grant-Hoffman et al. 2010; Peay et al. 2013). This project paved the way for a comprehensive understanding of seabird island ecosystem dynamics and the impacts of predator invasion upon them (Mulder et al.2011). David Towns and colleagues (Towns et al. 2016) describe how the 25 year history of rat eradications and research on the Mercury Islands contribute to our knowledge of seabird islands.

Another recent special issue of the New Zealand Journal of Ecology has also focused on the restoration of the worldfamous Tiritiri Matangi Island (Galbraith et al. 2013), which would not have been possible without first eradicating Pacific rats in 1993 (Veitch 2002). The recovery of the avifauna of the Mokohinau Islands has also just been comprehensively assessed for the first time since Pacific rat eradication (Ismar et al. 2014). The clear evidence of species and ecosystem recoveries on these Department of Conservation islands following some of the first rat eradications has now paved the way for island restoration on private islands. The eradication of cats and rats from privately owned Great Mercury Island in 2014 finally secures protection for the entire Mercury Island group. On the privately owned Noises, years of Norway rat reinvasion mis-diagnosed as eradication failure (Russell 2007) have now been addressed and led to species reintroductions in 2015. Eradications on mixed-tenure islands with multiple partners and coordinating agencies are also now more common. Project Island Song in the Bay of Islands is one such example of a successful eradication programme across multiple islands, stakeholders and land tenure. Undertaken in 2009 the programme saw the successful eradication of rodents and stoats from all islands of Ipipiri (eastern Bay of Islands), supported by ongoing biosecurity. However, eradication managers must be cautious to plan the future of rodent eradications in light of new challenges brought about by climate change (Courchamp et al. 2014), particularly coastal inundation of small islands in New Zealand.

\section{Conclusions}

After fifty years of rodent eradications in New Zealand, from the small to the massive, and from the accidental to the comprehensively planned, New Zealand has cleared invasive rodents and other predatory mammals from roughly a third of our islands larger than five hectares. However, these islands have tended to be small and uninhabited, and account for only $10 \%$ of offshore island area. Nonetheless these eradications have resulted in a 20 fold increase in invasive predator-free offshore island area from only $0.5 \%$ in 1963 (Russell et al. 2015). Although clearing $10 \%$ of offshore island estate of introduced predators is a laudable achievement, much more is possible. Eradication of introduced mammalian predators from Stewart Island/Rakiura and Great Barrier Island/Aotea would raise this statistic to $50 \%$ of offshore island estate. However, while incremental and step-change advances in technology underpinned the rodent eradication advances of the 1990s and advances in understanding rodent invasion biology underpinned the 2000s, the next challenge for eradication managers and biologists is engaging communities and stakeholders in all their diverse forms to work towards a common conservation goal such as pest eradication (Oppel et al. 2011; Glen et al. 2014).

New Zealand's record of having undertaken the world's largest rat eradication has now been surpassed, with the eradication of rodents and other introduced mammals from Macquarie Island (Springer 2016) and very massive 3,900 km² South Georgia Island. New Zealanders did, however, play an important role in both these eradications and have generally exported the knowledge of rodent eradications around the world (Samaniego-Herrera et al. 2011). Besides increased social complexity from resident human communities, moving beyond islands currently considered within our capability in New Zealand (perhaps 20,000 hectares) will also require a change in the methodology to avoid the logistics and costs overwhelming a project. For example, although mice have been recorded at less than one per hectare on the main Auckland Island (46,119 hectares), eradication still requires delivering a bait to every possible habitat (Russell \& Harper unpubl. data). Once again, developments in possum control point the way forward with bait application rates reduced by $90 \%$ since 1990 and reducing aircraft costs through better spreader bucket technology allowing faster sowing with wider swathes. The challenge will be to adapt these improvements to an eradication context where small mistakes can be fatal to success.

As 'mainland' predator control projects become more and more sophisticated, the distinction between eradication and 
control becomes less clear, with pests eradicated from some mainland sites (Burns et al. 2012), and some islands prone to constant reinvasion (Russell et al. 2009). Ultimately, what is important is not whether a site is surrounded by water, but the type of barrier present to prevent reinvasion following eradication, and the permeability of and osmotic pressure on that barrier. Only with ongoing improvement in eradication and barrier technology will permanent predator removal from any site in New Zealand be possible. However, in working towards a Predator Free New Zealand, we must not forget the many other pest species which require attention. We celebrated the $50^{\text {th }}$ anniversary of rodent eradications in New Zealand in 2014, but also celebrated the $100^{\text {th }}$ anniversary of large herbivore eradications in New Zealand in 2015, with the removal of goats (Capra hircus) from South East Island in 1915 (Clout \& Russell 2006).

\section{Acknowledgements}

The authors wish to thank the University of Auckland Centre for Biodiversity and Biosecurity and the Auckland Council Biosecurity Unit for supporting the symposium. The authors also wish to thank the New Zealand Journal of Ecology editor Jo Monks, technical editor Katherine Russell and all reviewers who supported this special issue, as well as a 2012 Prime Minister's Emerging Scientist Prize to JCR which supported publication. This review benefited from comments by David Towns and an anonymous reviewer.

\section{References}

Angel A, Wanless RM, Cooper J 2009. Review of impacts of the introduced house mouse on islands in the Southern Ocean: are mice equivalent to rats? Biological Invasions 11: 1743-1754.

Atkinson IAE 1973. Protection and use of the islands in the Hauraki Gulf Maritime Park. Proceedings of the New Zealand Ecological Society 20: 103-114.

Aviss M, Roberts A 1994. Pest fences: notes and comments. Threatened Species Occasional Publication No 5. Wellington, New Zealand, Department of Conservation. $18 \mathrm{p}$.

Bagasra A, Nathan HW, Mitchell MS, Russell JC 2016. Tracking invasive rat movements with a systemic biomarker. New Zealand Journal of Ecology 40: 267-272.

Bassett IE, Cook J, Buchanan F, Russell JC 2016. Treasure Islands: biosecurity in the Hauraki Gulf Marine Park. New Zealand Journal of Ecology 40: 250-266.

Bell BD 1978. The Big South Cape islands rat irruption. In: Dingwall PR, Atkinson PR, Hay C eds The ecology and control of rodents in New Zealand nature reserves. Wellington, New Zealand, Department of Lands and Survey Information Series No. 4. Pp. 33-45.

Bell EA, Bell BD, Merton DV 2016. The legacy of Big South Cape: rat irruption to rat eradication. New Zealand Journal of Ecology 40: 212-218.

Bellingham PJ, Towns DR, Cameron EK, Davis JJ, Wardle DA, Wilmshurst JM, Mulder CPH 2010. New Zealand island restoration: seabirds, predators, and the importance of history. New Zealand Journal of Ecology 34: 115-136.

Blackie HM, MacKay JW, Allen WJ, Smith DH, Barrett B, Whyte BI, Murphy EC, Ross J, Shapiro L, Ogilvie S, Sam
S, MacMorran D, Inder S, Eason CT 2014. Innovative developments for long-term mammalian pest control. Pest Management Science 70: 345-351.

Broome KG 2009. Beyond Kapiti-a decade of invasive rodent eradications from New Zealand islands. Biodiversity 10: 14-24.

Broome K, Cromarty P, Cox A, Griffiths R, McClelland P, Golding C 2011. The Island Eradication Advisory Group (IEAG) - a model of effective technical support for eradication project planning and management. Poster abstract In: Veitch CR, Clout MN, Towns DR eds Island invasives: eradication and management. Gland, Switzerland and Auckland, New Zealand, IUCN. Pp. 524.

Burns B, Innes J, Day T 2012. The use and potential of pest-proof fencing for ecosystem restoration and fauna conservation in New Zealand. In: Somers MJ, Hayward M eds Fencing for conservation: restriction of evolutionary potential or a riposte to threatening processes. New York, Springer. Pp. 65-90.

Campbell KJ, Beek J, Eason CT, Glen AS, Goodwin J, Gould F, Holmes ND, Howald GR, Madden FM, Ponder JB, Threadgill DW, Wegmann AS, Baxter GS 2015. The next generation of rodent eradications: innovative technologies and tools to improve species specificity and increase the feasibility of rodent eradications on islands. Biological Conservation 185: 47-58.

Clapperton BK 2006. A review of the current knowledge of rodent behaviour in relation to control devices. Science for Conservation 263. Wellington, New Zealand, Department of Conservation. $55 \mathrm{p}$.

Clout MN, Russell JC 2006. The eradication of mammals from New Zealand islands. In: Koike F, Clout MN, Kawamichi M, De Poorter M, Iwatsuki Keds Assessment and control of biological invasion risks. Gland, Switzerland, International Union for Conservation of Nature and Kyoto, Japan Shoukadoh Book Sellers. Pp. 127-141.

Clout MN, Russell JC 2008. The invasion ecology of mammals: a global perspective. Wildlife Research 35: 180-184.

Courchamp F, Chapuis JL, Pascal M 2003. Mammal invaders on islands: impact, control and control impact. Biological Reviews 78: 347-383.

Courchamp F, Hoffman BD, Russell JC, Leclerc C, Bellard C 2014. Climate change, sea-level rise and conservation: keeping island biodiversity afloat. Trends in Ecology and Evolution 29: 127-130.

Cromarty P, Broome K, Cox A, Empson RA, Hutchinson WM, McFadden I 2002. Eradication planning for invasive alien species on islands - the approach developed by the New Zealand Department of Conservation. In: Veitch CR, Clout MN eds Turning the tide: the eradication of invasive species. Gland, Switzerland and Cambridge, UK, IUCN. Pp. 85-91.

Davies D, Dilley BJ, Bond AL, Cuthbert RJ, Ryan PG 2015. Trends and tactics of mouse predation on Tristan Albatross Diomedea dabbenena chicks at Gough Island, South Atlantic Ocean. Avian Conservation and Ecology 10: 5.

Department of Conservation 2014. Briefing to the incoming minister. Wellington, New Zealand, Department of Conservation. $41 \mathrm{p}$.

Dilks PJ, Towns DR 2002. Developing tools to detect and respond to rodent invasions of islands: workshop report and recommendations. DOC Science Internal Series 59. Wellington, New Zealand, Department ofConservation. $19 \mathrm{p}$. Dingwall PR, Atkinson IAE, Hay C 1978. The ecology 
and control of rodents in New Zealand nature reserves. Proceedings of a symposium convened by the Department of Lands and Survey in Wellington, New Zealand on 2930 November 1976. Wellington, Department of Lands and Survey. $237 \mathrm{p}$.

Dowding JE, Murphy EC, Springer K, Peacock AJ, Krebs CJ 2009. Cats, rabbits, Myxoma virus, and vegetation on Macquarie Island: a comment on Bergstrom et al. (2009). Journal of Applied Ecology 46: 1129-1132.

Elliott GP, Greene TC, Nathan HW, Russell JC 2015. Winter bait uptake trials and related field work on Antipodes Island in preparation for mouse (Mus musculus) eradication. DOC Research and Development Series 345. Wellington, New Zealand, Department of Conservation. 34 p.

Empson RA, Miskelly CM 1999. The risks, costs and benefits of using brodifacoum to eradicate rats from Kapiti Island, New Zealand. New Zealand Journal of Ecology 23: 241-254.

Fukami T, Wardle DA, Bellingham PJ, Mulder CPH, Towns DR, Yeates GW, Bonner KI, Durett MS, Grant-Hoffman MN, Williamson WM 2006. Above- and below-ground impacts of introduced predators in seabird-dominated island ecosystems. Ecology Letters 9: 1299-1307.

Galbraith M, Craig J, Mitchell N, Cooper H 2013. Introduction to the special issue on Tiritiri Matangi Island. New Zealand Journal of Ecology 37: 257.

Glen AS, Atkinson R, Campbell KJ, Hagen E, Holmes ND, Keitt BS, Parkes JP, Saunders A, Sawyer J, Torres H 2013. Eradicating multiple invasive species on inhabited islands: the next big step in island restoration? Biological Invasions 15: 2589-2603.

Grantham HS, Wilson KA, MoilanenA, Rebelo T, Possingham HP 2009. Delaying conservation actions for improved knowledge: how long should we wait? Ecology Letters 12: 293-301.

Grant-Hoffman MN, Mulder CPH, Bellingham PJ 2010. Effects of invasive rats and burrowing seabirds on seeds and seedlings on New Zealand islands. Oecologia 162: 1005-1016.

Greenslade P, Burbidge AA, Jasmyn A, Lynch J 2013. Keeping Australia's islands free of introduced rodents: the Barrow Island example. Pacific Conservation Biology 19: 284-294.

Griffiths R, Buchanan F, Broome K, Neilsen J, Brown D, Weakley M 2015. Successful eradication of invasive vertebrates on Rangitoto and Motutapu Islands, New Zealand. Biological Invasions 17: 1355-1369.

Gsell A, Innes JG, de Monchy P, Brunton D 2010. The success of using trained dogs to locate sparse rodents in pest-free sanctuaries. Wildlife Research 37: 39-46.

Hadler MR, Buckle AP 1992. Forty five years of anticoagulant rodenticides - past, present and future trends. In: Borrecco JE, Marsh RE eds Proceedings of the Fifteenth Vertebrate Pest Conference. Davis, USA, University of California. Pp. 149-155.

Harper GA, Rutherford M 2016. Home range and population density of black rats (Rattus rattus) on a seabird island: a case for a marine subsidised effect? New Zealand Journal of Ecology 40: 219-228.

Hoare JM, Hare KM 2006. The impact of brodifacoum on non-target wildlife: gaps in knowledge. New Zealand Journal of Ecology 30: 157-167.

Holmes ND, Griffiths R, Pott M, Alifano A, Will D, Wegmann AS, Russell JC 2015. Factors associated with rodent eradication failure. Biological Conservation 185: 8-16.

Howald G, Donlan CJ, Galván JP, Russell JC, Parkes J, Samaniego A, Wang Y, Veitch CR, Genovesi P, Pascal M, Saunders A, Tershy B 2007. Invasive rodent eradication on islands. Conservation Biology 21: 1258-1268.

Ihimaera W 2006. The amazing adventures of Razza the rat. New Zealand, Raupo Publishing (NZ) Ltd. 56 p.

Innes J, Barker G 1999. Ecological consequences of toxin use for mammalian pest control in New Zealand - an overview. New Zealand Journal of Ecology 23: 111-127.

Innes J, Watts C, Fitzgerald NL, Thornburrow D, Burns B, MacKay J, Speedy C 2011. Behaviour of invader ship rats experimentally released behind a pest-proof fence, Maungatautari, New Zealand. In: Veitch CR, Clout MN, Towns DR eds Island invasives: eradication and management. Gland, Switzerland and Auckland, New Zealand, IUCN. Pp. 437-440.

Innes J, Lee WG, Burns B, Campbell-Hunt C, Watts C, Phipps H, Stephens 2012. Role of predator-proof fences in restoring New Zealand's biodiversity: a response to Scofield et al. (2011). New Zealand Journal of Ecology 36: 232-238.

Ismar SMH, Baird KA, Gaskin CP, Taylor GA, Tennyson AJD, Rayner MJ, Bettesworth D, Fitzgerald N, Landers TJ, Imber MJ 2014. A case of natural recovery after the removal of invasive predators - community assemblage changes in the avifauna of Burgess Island. Notornis 61: 188-195.

Jansen WP 1993. Eradication of Norway rats and rabbits from Moutohora (Whale Island), Bay of Plenty. Ecological Management 1: 10-15.

Jones HP 2010. Seabird islands take mere decades to recover following rat eradication. Ecological Applications 20: 2075-2080.

Kapa D 2003. Eradication of kiore and the fulfilment of kaitiakitanga obligations. Auckland University Law Review 9: 1326-1352.

Keitt B, Campbell K, Saunders A, Clout M, Wang Y, Heinz R, Newton K, Tershy B 2011. The global islands invasive vertebrate eradication database: a tool to improve and facilitate restoration of island ecosystems. In: Veitch CR, Clout MN, Towns DR eds Island invasives: eradication and management. Gland, Switzerland and Auckland, New Zealand, IUCN. Pp. 74-77.

MacKay JWB 2011. Improving the success of mouse eradication attempts on islands. $\mathrm{PhD}$ thesis. Auckland, University of Auckland. 119 p.

MacKay JWB, Russell JC, Murphy EC 2007. Eradicating house mice from islands: successes, failures and the way forward. In: Witmer GW, Pitt WC, Fagerstone KA eds Managing vertebrate invasive species: proceedings of an international symposium. Fort Collins, USDA/APHIS/ WS, National Wildlife Research Center. Pp. 294-304.

MacKay JWB, Murphy EC, Anderson SH, Russell JC, Hauber ME, Wilson DJ, Clout MN 2011. A successful mouse eradication explained by site-specific population data. In: Veitch CR, Clout MN, Towns DR eds Island invasives: eradication and management. Gland, Switzerland and Auckland, New Zealand, IUCN. Pp. 198-203.

MacKay JWB, Alexander A, Hauber ME, Murphy EC, Clout MN 2013. Does genetic variation among invasive house mice in New Zealand affect eradication success? New Zealand Journal of Ecology 37: 18-25.

Mark AF, Turner KS, West CJ 2001. Integrating nature 
conservation with hydro-electric development: conflict resolution with Lakes Manapouri and Te Anau, Fiordland National Park, New Zealand. Lake and Reservoir Management 17: 1-25.

Masuda BM, Jamieson IG 2013. Response of a reintroduced bird population to rat reinvasion and eradication. New Zealand Journal of Ecology 37: 224-213.

McClelland PJ 2011. Campbell Island-pushing the boundaries of rat eradications. In: Veitch CR, Clout MN, Towns DR eds Island invasives: eradication and management. Gland, Switzerland and Auckland, New Zealand, IUCN. Pp. 204-207.

McClelland PJ, Coote R, Trow M, Hutchins P, Nevins HM, Adams J, Newman J, Moller H 2011. The Rakiura Tîtī Islands Restoration Project: community action to eradicate Rattus rattus and Rattus exulans for ecological restoration and cultural wellbeing. In: Veitch CR, Clout MN, Towns DR eds Island invasives: eradication and management. Gland, Switzerland and Auckland, New Zealand, IUCN. Pp. 451-454.

McFadden I, Greene TC 1994. Using brodifacoum to eradicate kiore (Rattus exulans) from Burgess Island and the Knights Group of the Mokohinau Islands. Science and Research Series No. 70. Wellington, New Zealand, Department of Conservation. $18 \mathrm{p}$.

McFadden I, Towns DR 1991. Eradication campaigns against kiore (Rattus exulans) on Rurima Rocks and Korapuki Island, northern New Zealand. Science and Research Internal Report No. 97. Wellington, New Zealand, Department of Conservation. $18 \mathrm{p}$.

Miskelly CM, Fraser JR 2006. Campbell Island snipe (Coenocorypha undescribed sp.) recolonise subantarctic Campbell Island following rat eradication. Notornis 53: 353-359.

Montague TL 2000. The brushtail possum: biology, impact and management of an introduced marsupial. Lincoln, New Zealand, Manaaki Whenua Press. 292 p.

Moors PJ 1985. Eradication campaigns against Rattus norvegicus on the Noises Islands, New Zealand, using brodifacoum and 1080. In: Moors PJ ed Conservation of island birds. Technical Publication No. 3. Cambridge, UK, International Council for Bird Preservation. Pp. 143-155.

Mulder CP, Grant-Hoffman MN, Towns DR, Bellingham PJ, Wardle DA, Durrett MS, Fukami T, Bonner KI 2009. Direct and indirect effects of rats: does rat eradication restore ecosystem functioning of New Zealand seabird islands? Biological Invasions 11: 1671-1688.

Mulder CPH, Anderson WB, Towns DR, Bellingham PJ 2011. Seabird islands: ecology, invasion and restoration.Oxford, UK, Oxford University Press. 512 p.

Nathan HW, Clout MN, Murphy EC, Mackay JWB 2013. Strategies for detection of house mice on a recently invaded island. New Zealand Journal of Ecology 37: 26-32.

Nathan HW, Clout MN, MacKay JWB, Murphy EC, Russell JC 2015. Experimental island invasion of house mice. Population Ecology 57: 363-371.

Newhook FJ 1969. Coppermine Island and conservation. Biological Conservation 1: 313-317.

Newman DG 1994. Effects of a mouse, Mus musculus, eradication programme and habitat change on lizard populations of Mana Island, New Zealand, with special reference to McGregor's skink, Cyclodina macgregori. New Zealand Journal of Zoology 21: 443-456.

Ogden J, Gilbert J 2009. Prospects for the eradication of rats from a large inhabited island: community based ecosystem studies on Great Barrier Island, New Zealand. Biological Invasions 11: 1705-1717.

Oppel S, Beaven BM, Bolton M, Vickery J, Bodey TW 2011. Eradication of invasive mammals on islands inhabited by humans and domestic animals. Conservation Biology 25: 232-240.

Parkes J, Nugent G 2011. Introduction to the symposium on search and detection. New Zealand Journal of Ecology 35: 131.

Peay KG, Dickie IA, Wardle DA, Bellingham PJ, Fukami T 2013. Rat invasion of islands alters fungal community structure, but not wood decomposition rates. Oikos 122: 258-264.

Peters D 2015. Native Island rat eradication project report. Unpublished Department of Conservation report DOC2562032. Wellington, New Zealand, Department of Conservation.

Pitt WC, Berentsen AR, Shiels AB, Volker SF, Eisemann JD, Wegmann AS, Howald GR 2015. Non-target species mortality and the measurement of brodifacoum rodenticide residues after a rat (Rattus rattus) eradication on Palmyra Atoll, tropical Pacific. Biological Conservation 185: 36-46.

Rauzon MJ 2007. Island restoration: exploring the past, anticipating the future. Marine Ornithology 35: 97-107.

Robins JH, Miller SD, Russell JC, Harper GA, Fewster RM 2016. Where did the rats of Big South Cape Island come from? New Zealand Journal of Ecology 40: 229-234.

Russell JC 2007. Invasion ecology and genetics of Norway rats on New Zealand islands. PhD thesis. Auckland, University of Auckland. 225 p.

Russell JC, Clout MN 2005. Rodent incursions on New Zealand islands. In: Parkes J, Statham M, Edwards G eds Proceedings of the 13th Australasian Vertebrate Pest Conference. Lincoln, New Zealand, Landcare Research. Pp. 324-330.

Russell JC, Holmes ND 2015. Tropical island conservation: rat eradication for species recovery. Biological Conservation 185: $1-7$.

Russell JC, Towns DR, Anderson SH, Clout MN 2005. Intercepting the first rat ashore. Nature 437: 1107.

Russell JC, Clout MN, Towns DR 2007. Early detection and eradication of invading rats. In: Witmer GW, Pitt WC, Fagerstone KA eds Managing vertebrate invasive species: proceedings of an international symposium. Fort Collins, USDA/APHIS/WS, National Wildlife Research Center. Pp. 268-272.

Russell JC, Beaven BM, MacKay JWB, Towns DR, Clout MN 2008a. Testing island biosecurity systems for invasive rats. Wildlife Research 35: 215-221.

Russell JC, Towns DR, Clout MN 2008b. Review of rat invasion biology: implications for island biosecurity. Science for Conservation 286. Wellington, New Zealand, Department of Conservation. $53 \mathrm{p}$.

Russell JC, MacKay JWB, Abdelkrim J 2009. Insular pest control within a metapopulation context. Biological Conservation 142: 1404-1410.

Russell JC, McMorlandAJC, MacKay JWB2010a. Exploratory behaviour of colonizing rats in novel environments. Animal Behaviour 79: 159-164.

Russell JC, Miller SD, Harper GA, MacInnes HE, Wylie MJ, Fewster RM 2010b. Survivors or reinvaders? Using genetic assignment to identify invasive pests following 
eradication. Biological Invasions 12: 1747-1757.

Russell JC, Innes JG, Brown PH, Byrom AE 2015. PredatorFree New Zealand: conservation country. BioScience 65: 520-525.

Samaniego-HerreraA, Aguirre-MuñozA, Rodríguez-Malagón M, González-Gómez R, Torres-García F, Méndez-Sánchez F, Félix-Lizárraga M, Latofski-Robles M 2011. Rodent eradications on Mexican islands: advances and challenges. In: Veitch CR, Clout MN, Towns DR eds Island invasives: eradication and management. Gland, Switzerland and Auckland, New Zealand, IUCN. Pp. 350-355.

Samaniego-Herrera A,Anderson DP, Parkes JP, Aguirre-Muñoz A 2013. Rapid assessment of rat eradication after aerial baiting. Journal of Applied Ecology 50: 1415-1421.

Saunders A, Norton DA 2001. Ecological restoration at mainland islands in New Zealand. Biological Conservation 99: 109-119.

Scofield RP, Cullen R, Wang M2011.Are predator-prooffences the answer to New Zealand's terrestrial faunal biodiversity crisis? New Zealand Journal of Ecology 35: 312-317.

Shapira I, Walker E, Brunton DG, Raubenheimer D 2013. Responses to direct verus indirect cues of predation and competition in naïve invasive mice: implications for management. New Zealand Journal of Ecology 37:33-40.

Springer K 2016. Methodology and challenges of a complex multi-species eradication in the sub-Antarctic and immediate effects of invasive species removal. New Zealand Journal of Ecology 40: 273-278.

Taylor RH 1968. Introduced mammals and islands: priorities for conservation and research. Proceedings of the New Zealand Ecological Society 15: 61-67.

Taylor RH 1979a. How the Macquarie Island parakeet became extinct. New Zealand Journal of Ecology 2: 42-45.

Taylor RH 1979b. Predation on sooty terns at Raoul Island by rats and cats. Notornis 26: 199-202.

Taylor RH 2016. Early ecological research on rodents in New Zealand, 1946-1971: personal recollections. New Zealand Journal of Ecology 40: 205-211.

Taylor RH, Thomas BW 1989. Eradication of Norway rats (Rattus norvegicus) from Hawea-Island, Fjordland, using brodifacoum. New Zealand Journal of Ecology 12:23-32.

Taylor RH, Thomas BW 1993. Rats eradicated from rugged breaksea island (170 ha), Fiordland, New Zealand. Biological Conservation 65: 191-198.

Thomas BW, Taylor RH 2002. A history of ground-based rodent eradication techniques developed in New Zealand, 1959-1993. In: Veitch CR, Clout MN eds Turning the tide: the eradication of invasive species. Gland, Switzerland and Cambridge, UK, IUCN, SSC Invasive Species Specialist Group. Pp. 301-310.

Thomson GM 1922. The naturalisation of plants and animals in New Zealand. Cambridge, UK, Cambridge University Press. 632 p.

Towns DR, Borrelle SB, Thoresen J, Buxton RT, Evans A2016. Mercury Islands and their role in understanding seabird island restoration. New Zealand Journal of Ecology 40: 235-249.
Towns DR, Broome KG 2003. From small Maria to massive Campbell: forty years of rat eradications from New Zealand islands. New Zealand Journal of Zoology 30: 377-398.

Towns DR, Daugherty CH, Atkinson IAE 1990. Ecological restoration of New Zealand islands. Conservation Sciences Publication No. 2. Wellington, New Zealand, Department of Conservation. $320 \mathrm{p}$.

Towns DR, Stephens T 1997. Island management and commercial sponsorship: the Mercury Islands experience. Science and Research Series No. 103. Wellington, New Zealand, Department of Conservation. 25 p.

Towns DR, Parrish GR, Tyrrell CL, Ussher GT, Cree A, Newman DG, Whitaker A, Westbrooke I 2007. Responses of tuatara (Sphenodon punctatus) to removal of introduced Pacific rats from islands. Conservation Biology 21: 1021-1031.

Towns DR, Wardle DA, MulderCP, Yeates GW, Fitzgerald BM, Parrish GR, Bellingham PJ, Bonner KI 2009. Predation of seabirds by invasive rats: multiple indirect consequences for invertebrate communities. Oikos 118: 420-430.

Towns DR 2011. Eradications of vertebrate pests from islands around New Zealand: what have we delivered and what have we learned. In: Veitch CR, Clout MN, Towns DR eds Island invasives: eradication and management. Gland, Switzerland and Auckland, New Zealand, IUCN. Pp. 364-371.

Towns DR, Bellingham PJ, Mulder CPH, Lyver POB 2012. A research strategy for biodiversity conservation on New Zealand's offshore islands. New Zealand Journal of Ecology 36: 1-20.

Towns DR, West CJ, Broome KG 2013. Purposes, outcomes and challenges of eradicating invasive mammals from New Zealand islands: an historical perspective. Wildlife Research 40: 94-107.

Veitch D, Fitzgerald M, Innes J, Murphy E 1992. Proceedings of the national predator management workshop. Threatened Species Occasional Publication No 3. Wellington, New Zealand, Department of Conservation. $41 \mathrm{p}$.

Veitch CR 2002. Eradication of Pacific rats (Rattus exulans) from Tiritiri Matangi Island, Hauraki Gulf, New Zealand. In: Veitch CR, Clout MN eds 2002. Turning the tide: the eradication of invasive species. Gland, Switzerland and Cambridge, UK, IUCN. Pp. 360-364.

Veitch CR, Clout MN 2002. Turning the tide: the eradication of invasive species. Gland, Switzerland and Cambridge, UK, IUCN. 414 p.

Veitch CR, Clout MN, Towns DR 2011. Island invasives: eradication and management. Gland, Switzerland and Auckland, New Zealand, IUCN. 542 p.

Wardle DA, Bellingham PJ, Bonner KI, Mulder CPH 2009. Indirect effects of invasive predators on litter decomposition and nutrient resorption on seabirddominated islands. Ecology 90: 452-464.

Wodzicki KA 1950. Introduced mammals of New Zealand: an ecological and economic survey. DSIR Bulletin 98, Wellington, New Zealand. 255 p.

Young D 2004. Our islands, our selves. Dunedin, New Zealand, University of Otago Press. 298 p. 